\title{
Językowa a celowościowa wykładnia przepisów polskiego prawa podatkowego
}

W polskiej myśli prawniczej panuje ugruntowany pogląd o tym, że dominującym rodzajem wykładni przepisów prawa podatkowego powinna być wykładnia językowa, a posługiwanie się pozajęzykowymi regułami wykładni powinno być dokonywane $\mathrm{z}$ najwyższą ostrożnością. $\mathrm{W}$ orzecznictwie i piśmiennictwie wskazuje się jednak niejednokrotnie przykłady przepisów, których prawidłowa interpretacja nie może zostać przeprowadzona bez odwołania się do pozajęzykowych reguł wykładni. Celem niniejszego artykułu jest próba uporządkowania problematyki relacji pomiędzy językowymi i pozajęzykowymi regułami wykładni przepisów polskiego prawa podatkowego (ze szczególnym uwzględnieniem wykładni celowościowej) oraz wskazanie, w jakich sytuacjach możliwe jest wyjście poza granice znaczeniowe użytych przez ustawodawcę słów, a nawet interpretacja dokonana wbrew wyraźnemu językowemu brzmieniu tego przepisu.

Potrzeba nadania szczególnego znaczenia wykładni językowej przepisów podatkowych wynika przede wszystkim z dwóch przyczyn.

Po pierwsze, wykładnia językowa uznawana jest powszechnie za podstawowy rodzaj wykładni prawa w ogóle. Przekonanie to opiera się na założeniu, że podstawą komunikacji międzyludzkiej jest język i jeżeli zrekonstruowania treści normy prawnej „można dokonać w jeden i tylko jeden sposób, uzyskując normy między sobą zgodne, to odwoływanie się do innego sposobu wykładni naruszałoby zasady kultury prawnej państwa praworządnego"l. Dopiero w sytuacji, gdy język przepisów prawnych nie jest jednoznaczny, tzn. na podstawie samego brzmienia przepisów można odtworzyć kilka norm, albo w ogóle trudno jest zrozumieć sens analizowanego przepisu, należy sięgnąć do innych niż językowa rodzajów wykładni prawa ${ }^{2}$. Zasada clara non sunt interpretanda jest jednak przedmiotem dyskusji, która w literaturze przedmiotu toczy się od ponad 50 lat

* Dr hab. Ryszard Sowiński - Katedra Prawa Finansowego, Wydział Prawa i Administracji, Uniwersytet im. Adama Mickiewicza w Poznaniu.

${ }^{1}$ Z. Ziembiński, Logika praktyczna, Warszawa 2007, s. 37.

${ }^{2}$ Ibidem. 
- dyskusja ta wiąże się z przedstawionym w tytule pytaniem o relacje pomiędzy językowymi a pozajęzykowymi rodzajami wykładni³.

$\mathrm{Na}$ gruncie prawa podatkowego wykładni językowej nadaje się szczególne znaczenie również ze względu na to, że jest ono częścią prawa publicznego, w którym akcentuje się potrzebę precyzyjnego zdefiniowania granic obowiązków adresatów norm prawnych wobec państwa. Normy prawa podatkowego wkraczają bardzo głęboko w sferę wolności, własności i prywatności podatników - dlatego postulat szczególnej dbałości o jakość językową przepisów jest na gruncie prawa podatkowego wyją̧tkowo uzasadniony. Już ponad 200 lat temu A. Smith zwracał uwagę na konieczność stanowienia precyzyjnej legislacji, ponieważ „podatnik musi mieć pewność co do tego, jakie są jego obowiązki, ale też jakie są jego uprawnienia w związku z ustaleniem i zapłatą podatku [...]. Termin płatności, sposób zapłaty, sumę, jaką należy zapłacić [...] wszystko to powinno być jasne i zrozumiałe dla podatnika"4. We współczesnych czasach podkreśla się, że nadanie wykładni językowej znaczenia szczególnego jest $\mathrm{w}$ istocie jedną $\mathrm{z}$ form realizacji zasady pewności prawa, rozumianej jako ochrona zaufania ${ }^{5}$. Gdyby podmioty dokonujące wykładni nie były związane językowymi granicami, „całe prawodawstwo miałoby charakter tylko pozorny, nieodpowiadający wyobrażeniom o praworządności”.

W literaturze przedmiotu toczy się dyskusja na temat granic wyłączności wykładni językowej oraz sytuacji, w których dopuszczalne jest odwoływanie się do pozajęzykowych reguł wykładni. W dyskusji tej wskazuje się:

- na sytuacje, w których wyjście poza językowe znaczenie słów użytych przez ustawodawcę jest w ogóle niedopuszczalne;

- na sytuacje, w których pozajęzykowe reguły wykładni pozwalają jedynie na doprecyzowanie lub wybranie spośród wielu możliwych rezultatów interpretacji tekstu prawnego rezultatu najbardziej zgodnego z wartościami leżącymi u podstaw danego aktu prawnego, danej dziedziny prawa czy prawa w ogóle oraz

- na sytuacje, w których użycie pozajęzykowych reguł wykładni może być dokonane nawet wbrew dosłownemu, „literalnemu” brzmieniu przepisów.

$\mathrm{Na}$ niedopuszczalność stosowania pozajęzykowych reguł wykładni wskazuje się co najmniej w czterech przypadkach ${ }^{7}$ : (1) w przypadku interpretacji skonstruowanych przez ustawodawcę definicji; (2) w przypadku przepisów regulujących kompetencje organów państwa; (3) w przypadku, w którym użycie pozajęzykowych reguł wykładni prowadziłoby do pogorszenia sytuacji jednostki; (4) w przypadku regulacji zawierających wyjątki od zasad ogólnych, zgodnie $\mathrm{z}$ tradycyjną formułą exeptiones non sunt extentendae.

${ }^{3}$ K. Płeszka, Wykładnia rozszerzajaca, Warszawa 2010, s. 187.

${ }^{4}$ A. Smith, Badania nad natura i przyczynami bogactwa narodów, t. 2, Warszawa 1954, s. 585.

5 T. Spyra, Granice wyktadni prawa, Warszawa 2006, s. 270.

${ }^{6}$ S. Wronkowska, Z. Ziembiński, Zarys teorii prawa, Poznań 2001, s. 167.

${ }^{7}$ B. Brzeziński, Wyktadnia przepisów prawa finansowego, [w:] C. Kosikowski, System prawa finansowego, t. I, Warszawa 2010, s. 295. 
Pomimo słusznego i dość jednoznacznego określenia sytuacji, w których wyłączono możliwość użycia pozajęzykowych metod wykładni, warto zwrócić uwagę, że wymienione ograniczenia nie zawsze mają charakter bezwzględny. Obserwując ewolucję polskiego prawa podatkowego, wskazać można na przykład na szereg przepisów zawierających definicje niejasne, niejednoznaczne i niedające się interpretować bez odwołania do istoty instytucji, których dotyczą, oraz celu regulacji. Usunięcia tych niejasności nie da się dokonać, nie wychodząc poza granice wykładni językowej. Panuje także zgodność co do tego, że użycie wykładni pozajęzykowej nie powinno w żadnym przypadku pogarszać sytuacji podatnika ${ }^{8}$.

W literaturze poświęconej zagadnieniom wykładni prawa zwraca się uwagę na zasadę zakazu dokonywania interpretacji rozszerzającej, zawierającej wyjątki od bardziej ogólnych zasad prawnych (exeptiones non sunt extentendae). W przypadku prawa podatkowego regułę taką stosuje się w szczególności do interpretacji przepisów regulujących zwolnienia, ulgi i wyłączenia określonych stanów faktycznych lub prawnych z opodatkowania. Interpretacja wyjątków, w świetle konstytucyjnej zasady powszechności obowiązku podatkowego, powinna być realizowana przy użyciu reguł wykładni językowej dokonywanej w sposób ścisły (tzw. ścisła, literalna wykładnia przepisów) ${ }^{9}$.

W literaturze spotyka się często odwołanie do tradycyjnej formuły clara non sunt interpretanda. Formuła ta służy za uzasadnienie ograniczenia stosowania pozajęzykowych rodzajów wykładni do przypadków wyraźnie uzasadnionych. Ta tzw. klaryfikacyjna koncepcja wykładni prawa uznawana jest współcześnie za zbyt uproszczoną, a opisywanej formule przeciwstawia się dwie inne. Zasada interpretatio cessat in claris oznacza potrzebę prowadzenia procesu wykładni tak dogłębnie i z użyciem takich metod, które pozwolą na osiągnięcie przekonania co do jednoznaczności rezultatu wykładni. Paremia interpretatio cessat in claris jest - jak trafnie ujął B. Brzeziński - uproszczonym, siłą rzeczy, wyrazem derywacyjnej koncepcji wykładni rozwijanej przez Z. Ziembińskiego i M. Zielińskiego ${ }^{10}$. Derywacyjna koncepcja wykładni zakłada konieczność używania wszystkich możliwych w danym przypadku rodzajów wykładni do wszystkich przepisów, przy czym poszczególne rodzaje wykładni powinny być wykorzystywane w odpowiedniej kolejności (tzn. wykładnia językowa - systemowa - celowościowa) ${ }^{11}$. W tym kontekście zasada interpretatio cessat in claris może zostać uzupełniona o maksymę omnia sunt interpretanda. Dyskusja nad tym, w jakim zakresie aktualna pozostaje zasada clara non sunt interpretanda, a w jakim przy interpretacji tekstu prawego należy uznawać zasadę omnia sunt interpretanda, jest obecnie jedną $\mathrm{z}$ istotnych dyskusji prowadzonych nie tylko na gruncie prawa

\footnotetext{
${ }^{8}$ Ibidem.

9 Ibidem, s. 288 .

${ }^{10}$ Zob. szerzej: M. Zieliński, Wykładnia prawa. Zasady, reguły, wskazówki, Warszawa 2010.

${ }_{11}$ T. Spyra, op. cit., s. 73.
} 
finansowego ${ }^{12}$. Dyskusja ta ma wymiar praktyczny - przyjęcie tej ostatniej zasady oznaczałoby na przykład zmianę panującego do tej pory w orzecznictwie przekonania o aktualności zasady clara non sunt interpretanda oraz zasady interpretatio cessat in claris $^{13}$.

Uwagi o prymacie wykładni językowej na gruncie prawa podatkowego nie oznaczają zatem wyłączności tego rodzaju wykładni. W procesie wykładni przepisów należy stosować pozajęzykowe reguły wykładni, aby (w granicach językowego znaczenia zwrotów użytych przez ustawodawcę) osiągać wynik wykładni jak najbardziej spójny z celami regulacji oraz wartościami chronionymi i realizowanymi przez system prawa, a także dokonywać kontroli zgodności rezultatów wykładni m.in. z chronionymi prawnie wartościami.

W tym miejscu pojawia się zatem pytanie o to, kiedy reguły wykładni pozajęzykowej mogą prowadzić do interpretacji niezgodnej z językowym znaczeniem analizowanych przepisów. Pytanie to jest szczególnie istotne, gdy mamy do czynienia z niezgodnością rezultatu wykładni językowej np. z wartościami konstytucyjnymi czy zdrowym rozsądkiem (wykładnia ad absurdum). Problem ten zawarł T. Spyra w pytaniu o to, ,jak daleko można się posunąć w twórczym odczytaniu teksu prawnego, jakie są kryteria przesądzające o tym, że decyzję interpretacyjną «da się jeszcze pogodzić z tekstem»"14. Na tak postawione pytanie odpowiada się, wskazując trzy przesłanki dopuszczalności podważenia rezultatów wykładni językowej ${ }^{15}$ :

- wykładnia pozajęzykowa ma na celu zamknięcie luki w prawie;

- wykładnia językowa prowadzi do absurdalnych wniosków;

- wykładnia językowa prowadzi do wyniku sprzecznego z podstawowymi wartościami prawa, w tym w szczególności z wartościami wynikającymi z Konstytucji.

Kwestia stosowania reguł wykładni pozajęzykowej w przypadku istnienia tzw. luk w prawie budzi kontrowersje, choćby dlatego że kontrowersje wywołuje samo pojęcie luki w prawie. Powszechnie akceptuje się obecnie zasadę, zgodnie z którą niedopuszczalne byłoby uzupełnianie, w drodze wykładni, tzw. aksjologicznych luk w prawie w sytuacji, w której interpretacja taka byłaby niekorzystna dla podatnika ${ }^{16}$ - reguła ta odnosi się zresztą $\mathrm{w}$ ogóle do stosowania pozajęzykowych metod wykładni wbrew wynikowi wykładni językowej. Znane są natomiast przypadki wypełnienia luki aksjologicznej poprzez analogię. Przykładem zastosowania pozajęzykowych reguł wykładni w celu uzupełnienia luki aksjologicznej było zastosowanie (w drodze analogii) przepisów dotyczących podatnika do płat-

\footnotetext{
${ }_{12}$ Zob. szerzej: K. Płeszka, op. cit.

13 Ibidem, s. 231.

${ }_{14}$ T. Spyra, op. cit.

${ }_{15}$ B. Brzeziński, Podstawy wyktadni prawa podatkowego, Gdańsk 2008, s. 55.

16 Ibidem, s. 93.
} 
ników podatku ${ }^{17}$. Warto w tym miejscu wskazać, że na gruncie teorii prawa istnieją rozbieżności co do potrzeby odróżnienia wykładni od analogii - część autorów preferuje odróżnienie tych dwóch pojęć, a część proponuje traktowanie analogii jako odmiany wykładni ${ }^{18}$.

Luka aksjologiczna pojawia się wtedy, gdy jakaś regulacja (lub jej brak) prowadzi do rezultatów sprzecznych z czyimiś ocenami dotyczącymi celu regulacji. Zgodnie z powszechnie panującym przekonaniem luki aksjologiczne mają charakter pozorny ${ }^{19}$, choć warto zwrócić przy tym uwagę, że tocząca się od wielu lat dyskusja nad wprowadzeniem do systemu podatkowego kontrowersyjnej ogólnej klauzuli obejścia ustawy podatkowej może być interpretowana jako próba znalezienia narzędzia, które pozwoli na kompleksowe rozwiązanie problemu wykorzystywania przez podatników licznych luk aksjologicznych umożliwiających tzw. optymalizację podatkową.

O ile za dopuszczalne w wyjątkowo uzasadnionych przypadkach należy uznać wypełnianie np. w drodze analogii luk aksjologicznych, to w przypadku tzw. luk konstrukcyjnych użycie wykładni pozajęzykowej wydaje się usprawiedliwione, przy czym pamiętać należy o konieczności ochrony podatnika poprzez niedokonywanie niekorzystnej dla niego interpretacji wychodzącej poza językowe znaczenie analizowanych przepisów. Zgodnie z koncepcją M. Zielińskiego, użycie pozajęzykowych reguł wykładni może być formą realizacji co najmniej dwóch funkcji wykładni: funkcji naprawczej oraz uzupełniająco-kreującej. Ta pierwsza funkcja polega na eliminowaniu w procesie wykładni skutków błędów popełnianych przez ustawodawcę w procesie tworzenia prawa. Natomiast funkcja uzupełniająco-kreująca wiąże się z dodaniem w procesie wykładni ,pewnych elementów normatywnych, które - zapewne przez niedopatrzenie legislacyjne - nie znalazły się w tekście prawnym, a bez których nie mogą funkcjonować niektóre istotne wprowadzone przez ustawodawcę instytucje" ${ }^{20}$. W polskim piśmiennictwie podatkowym można obserwować ewolucję poglądów na temat dopuszczalności stosowania wykładni per analogiam - pomimo początkowych kontrowersji, obecnie uznaje się dopuszczalność użycia tego typu wykładni, a dyskusja dotyczy raczej granic tej dopuszczalności ${ }^{21}$.

W literaturze podkreśla się możliwość wyjścia poza językowe znaczenie słów i wyrażeń użytych w przepisach w sytuacji, w której ich językowa wykładnia prowadzi do absurdu oraz w sytuacji, gdy „odtworzona z tekstu norma

${ }^{17} \mathrm{~K}$. Karpus, Wyktadnia w prawie podatkowym - przeglad problematyki, [w:] L. Morawski (red.), Wykładnia prawa i inne problemy filozofii prawa, Toruń 2005, s. 141.

18 T. Spyra, op. cit., s. 76.

19 S. Wronkowska, Z. Ziembiński, op. cit., s. 183 i n.

${ }^{20}$ M. Zieliński, op. cit., s. 231 i n.

${ }_{21}$ M. Gontarczyk, Analogia legis w prawie podatkowym, [w:] L. Leszczyński (red.), Wykładnia prawa. Odrębności w wybranych gatęziach prawa, Lublin 2006, s. 53; R. Mastalski, Prawo podatkowe I-część ogólna, Warszawa 1998, s. 106. 
nie znajdowałaby uzasadnienia aksjologicznego albo wręcz nakazywała czynić coś, co w świetle ocen przypisywanych «prawodawcy» zasługiwałoby na potępienie"22 (argumentum ab inutili sensu, ab absurdo). W prawie podatkowym funkcjonują przepisy, które odgrywają istotną rolę w konstrukcji podatku, ale ich ścisła językowa interpretacja oraz konsekwentne stosowanie prowadziłoby do sytuacji sprzecznych ze zdrowym rozsądkiem. Przykładem są przepisy o opodatkowaniu podatkiem dochodowym otrzymanych przez podatnika nieodpłatnych świadczeń niebędących darowiznami - ich dosłowna interpretacja doprowadziłaby do opodatkowania codziennych zdarzeń, których opodatkowania ustawodawca z pewnością nie zakładał. Podobnie, jako przykład, wskazać można brak przepisów zwalniających podatników będących osobami fizycznymi nieprowadzącymi działalności gospodarczej z konieczności zapłaty podatku od otrzymanych pożyczek, przy objęciu pożyczki zakresem ustawowej definicji przychodów. Pomimo braku wyraźnego zwolnienia ani organy podatkowe, ani podatnicy nie uznają środków pieniężnych otrzymanych w ramach umowy pożyczki za opodatkowane przychody.

Wyjście poza granice językowego znaczenia przepisów jest dopuszczalne również wtedy, gdy rezultat wykładni językowej stoi w sprzeczności z wartościami konstytucyjnymi, choć takie rozwiązanie powinno być uznawane za dopuszczalne tylko w wyjątkowych sytuacjach. W literaturze podkreśla się konieczność „prokonstytucyjnej” wykładni przepisów, a Trybunał Konstytucyjny wskazuje wyraźnie w jednym z wyroków, że ,językowe znaczenie tekstu prawnego stanowi granicę wykładni w tym sensie, że nie jest dopuszczalne przyjęcie swoistych wyników wykładni funkcjonalnej, jeżeli wykładnia językowa prowadzi do jednoznaczności tekstu prawnego. Nie oznacza to jednakże, że granica wykładni, jaką stanowić może językowe znaczenie tekstu, jest granicą bezwzględną. Oznacza to jedynie, że do przekroczenia tej granicy niezbędne jest silne uzasadnienie aksjologiczne, odwołujące się przede wszystkim do wartości konstytucyjnych"23. Kwestia interpretacji przepisów, których zgodność z konstytucją budzi uzasadnione wątpliwości, jest przedmiotem dyskusji w literaturze przedmiotu - dyskusja ta dotyczy rozumienia zasady bezpośredniego stosowania konstytucji ${ }^{24}$ i odpowiedzi, na przykład, na pytanie, czy „normy konstytucyjne mogą być materialnoprawną podstawą orzeczenia sądu, [...] czy w razie konfliktu normy ustawowej z konstytucyjną sąd jest upoważniony odmówić zastosowania tej pierwszej i wydać orzeczenie na podstawie normy wyrażonej w Konstytucji, nie skierowując sprawy do Trybunału Konstytucyjnego" 25 .

${ }^{22}$ Z. Ziembiński, op. cit., s. 242.

${ }^{23}$ Zobacz: Wyrok TK z 28 czerwca 2000 r., K 25/99.

${ }^{24}$ L. Morawski, Główne problemy współczesnej filozofii prawa. Prawo w toku przemian, Warszawa 2003, s. 238 i n.

${ }^{25}$ Zob. szerzej D. Mączyński, R. Sowiński, Ochrona podatnika przed skutkami funkcjonowania przepisów niezrozumialych, „Przegląd Podatkowy” 2005, nr 12. 
Konieczność odwoływania się do pozajęzykowych reguł wykładni przepisów podatkowych jest zazwyczaj skutkiem błędów popełnianych w procesie legislacyjnym - to konsekwencja m.in. wprowadzania przepisów zawierających błędy konstrukcyjne, stosowania rozbudowanego systemu odniesień, używania zdań wielokrotnie złożonych, stosowania pojęć nieostrych, braku spójności wewnętrznej aktów prawnych, rozproszenia materii w wielu aktach prawnych, braku przepisów intertemporalnych ${ }^{26}$. Wyjątkowo, np. w przypadku użycia przez ustawodawcę klauzul generalnych (np. interes publiczny), z góry zakłada się potrzebę sięgnięcia po ten rodzaj wykładni. W dyskusji, jaka toczy się od wielu lat w literaturze przedmiotu, zaobserwować można stopniowe zwiększanie znaczenia, jakie przypisuje się wykładni pozajęzykowej - dzieje się tak m.in. w związku z dyskusją o zasadach interpretacji przepisów prawa europejskiego czy też o stosowaniu tzw. wykładni ekonomicznej (gospodarczej) przepisów podatkowych ${ }^{27}$. Ochrona podatnika wymaga jednak uznania wykładni językowej za rodzaj wykładni o znaczeniu podstawowym - odejście od tej zasady oznaczałoby pobłażliwość dla niezadowalającego stanu legislacji podatkowej.

${ }^{26}$ Ibidem.

27 Zob. C. Kosikowski, E. Ruśkowski, A. Borodo, Finanse publiczne i prawo finansowe, Warszawa 2008, s. 84. 